\title{
MEASURING SYSTEMATIC RISK OF UNQUOTED AGRICULTURAL FARMS
}

\author{
Marián Tóth ${ }^{1}$, Drahoslav Lančarič $*^{2}$, Andrea Piterková ${ }^{1}$, Radovan Savov ${ }^{2}$, Tomáš Rábek ${ }^{1}$
}

\author{
Address: \\ ${ }^{1}$ Slovak University of Agriculture, Faculty of Economics and Management, Department of Finance, A. Hlinku 2, 94976 Nitra, Slovak Republic, \\ +421376414164 \\ ${ }^{2}$ Slovak University of Agriculture, Faculty of Economics and Management, Department of Management, A. Hlinku 2, 94976 Nitra, Slovak \\ Republic, +421376414168 \\ *Corresponding author: drahoslav.lancaric@uniag.sk
}

\begin{abstract}
In this paper we estimate systematic risk of the Slovak unquoted agricultural farms - agricultural cooperatives and companies, in the period of 2009-2012. An alternative Markowitz portfolio theory approach was applied. As a measure of the systematic risk, we used return on equity (ROE). Based on the dataset of 996 farms over years 20092012, the Slovak farm average ROE reached 0.048\% and systematic risk 3\%. The Slovak agricultural farms displayed low profitability. The average ROE was higher and systematic risk indicator was lower for agricultural companies than for agricultural production cooperatives. Thus the agricultural companies could be more attractive for investors.
\end{abstract}

Keywords: systematic risk, unquoted agricultural farms, return on equity

JEL: R52, R58, H41

\section{INTRODUCTION}

Risk is one of the main factors influencing the investment decision making process. Risk generally refers to the deviation of a considered indicator, and the risk's magnitude depends on the magnitude of volatility during a certain period. Total risk is typically measured, according to the Markowitz portfolio theory, by the mean-variance model and the standard deviation of stock return (Brealey and Myers 2008). Not all businesses raise their capital in the form of stocks traded on the stock market. These businesses represent unquoted companies.

The systematic and unsystematic risk belongs to the concept of Capital Asset Prising Model (CAPM) (Sharpe 1964; Lintner 1965) built on the mean-variance portfolio work of Markowitz (1952). While the unsystematic risk reflects the firm specific risk sources that might be eliminated by the diversification, the systematic risk remains common for all entities in a particular sector and can be termed as the market risk. (Brealey and Myers, 2008). The systematic risk measurement in the CAPM, also originally considers the volatility of stock prices and expected returns on securities. Very closely related to the CAPM is the Simple index model (SIM) equation, which is virtually identical to the CAPM equation, but without equilibrium asset pricing implications (Sharpe 1963, Hubbs et al. 2009). It means, the model can also be applied to other markets, not only the security market. It empowers the assumption to measure the systematic risk of unquoted companies, using alternatively the equity ratio. The stocks, considered in the original model, represent the equity securities, and the return on stock reflects simply the return on equity invested into the business. Therefore, it might be assumed, that deviation of return on equity could be considered for measurement of risk for unquoted companies.

The systematic risk can vary across industries, since industries show various resistance patterns against the risk, due to different business attributes (Lee and Jang 2006). The entities operating within the agricultural sector belong to the unquoted companies, whose securities are not traded on the public stock exchange. The systematic risk estimation in the agricultural sector requires the alternative Markowitz theory approach or SIM implication, when the input variables used in the analysis are the accounting fundamentals of companies. This alternative approach was applied in the number of previous studies, such as usage of gross and net returns (Gempesaw et al. 1988), crop revenues (Mumey et al. 1992) farm equity returns (Baginski and Wahlen 2003), book to market ratios (Fama and French 1995) or cash flow variability (Campbell and Vuolteenaho 2004; Cohen et al. 2009; Da, 2009).

The risk analysis of agriculture, using the Markowitz approach or Single index model, has been applied in a number of studies. Many of them did not have an aggregate character. They mainly focused on the certain part of agricultural production, for example, Barry (1980) applied the CAPM assumptions to estimate beta for the U.S. farm real estate market, Peterson and Leuthold (1987) used the portfolio approach to examine the cattle feeding problem, Prattley et al. (2007) applied the portfolio concept to find appropriate allocation of surveillance resources in animal populations, Barkley et 
al. (2010) estimated optimal crop diversification. A more aggregate perspective, when the systematic and nonsystematic risk of agriculture of a whole country is estimated, can be found as well. Gempesaw et al. (1988) applied the model to Delaware farm sector market portfolio, Turvey and Driver (1987) used SIM to study the systematic and non-systematic risk of the Canadian agriculture. Libbin et al. (2004) applied the Markowitz portfolio model directly to a series of representative New Mexico farms.

The most agricultural land in Slovakia is cultivated by the unquoted agricultural production cooperatives and the agricultural commercial companies (e.g. limited liability companies, joint stock companies). The main objective of the paper is to measure the systematic risk of these Slovak unquoted agricultural farms - cooperatives and companies, using the alternative Markowitz portfolio theory approach.

\section{DATA AND METHODS}

\section{Data}

Data from database of the Slovak Ministry of Agriculture and Rural Development (IL MoARD, 2013), over the period 2009-2012. The database consists of individual farm data, including balance sheets and income from financial statements. Data submission is obligatory for all agricultural. For our analysis, data were selected according to the farm legal form to subset of the agricultural production cooperatives (461) and the subset of the capital companies - Joint Stock Company (JSC) and Limited Liability Companies (Ltd.) (535). From the dataset data of the following farms were excluded:

- farms that started or quitted during the observed period 2009-2012,

- farms with negative equity (liabilities exceeding total assets),

- farms with return on equity (ROE) exceeding +/$100 \%$ (average profit or loss exceeds equity) over the observed period.

We used then data of 996 farms, out of which there were 535 agricultural companies and 461 agricultural productive cooperatives.

\section{Methods}

We assumed, that the return of the investor is based on the profit of the company and the equity invested into the business. Therefore, we considered return on equity ROE (Eq. 1) to be equivalent to the return on stocks, generally used in the case of quoted companies.

$$
R O E_{i}=\frac{\text { Earnings } \text { After } \text { Taxes }}{\text { Shareholders' } \text { Equity }}
$$

Measuring of volatility of return in the Markowitz portfolio theory is based on the average return over the observed period for each investment. We calculated the average return on equity $\operatorname{EROE}_{\mathrm{i}}$ (Eq. 2) for each individual farm.

$$
E R O E_{i}=\sum_{t=1}^{T} R O E_{i t} \cdot d_{t}
$$

Where:

$\mathrm{d}_{\mathrm{t}}$ - a weight of $R O E_{i t}$ over the observed period $\mathrm{t}$; $\mathrm{T}=4$.

The individual risk of each farm $\left(\sigma_{i}\right)$ is calculated using the standard deviation.

$\sigma_{i}=\sqrt{\sum_{t=1}^{T}\left(R O E_{i t}-E R O E_{i}\right)^{2} \cdot d_{t}}$

Where:

$\sigma_{i}$ - standard deviation of the individual return on equity (individual farm risk),

$R O E_{\text {it }}$ - individual return on equity,

$E R O E_{\mathrm{i}}$ - average individual return on equity.

The portfolio (systematic) risk $\left(\sigma_{p}\right)$ is determined by three variables:

$\mathrm{w}_{\mathrm{i}}$ - weight of the individual investment in portfolio,

$\sigma_{i}$ - standard deviation of the individual investment (individual risk),

$\sigma_{i j}$ - covariance (relation between the $\mathrm{ROE}_{\mathrm{i}}$ and $\mathrm{ROE}_{\mathrm{j}}$ ).

To take into account the market portfolio of all agriculture farms, the weight $\mathrm{w}_{\mathrm{i}}$ of each farm is determined by farm market share, which is the share of the farm`s equity on the total equity of all farms.

The covariance represents the relationship between returns on equity of farms (Eq. 4) and then $\Sigma$ is the covariance matrix (Eq. 5).

$$
\begin{aligned}
\sigma_{i j}= & \frac{1}{n} \sum_{i=1}^{n}\left(R O E_{i}-E R O E_{i}\right)\left(R O E_{\mathrm{j}}-E R O E_{j}\right) \\
\Sigma & =\left[\begin{array}{cccc}
\sigma_{11} \sigma_{12} & \sigma_{13} & \ldots & \sigma_{1 k} \\
\sigma_{21} \sigma_{22} & \sigma_{23} & \ldots & \sigma_{2 k} \\
\sigma_{31} \sigma_{32} & \sigma_{33} & \ldots & \sigma_{3 k} \\
& \ldots & & \\
\sigma_{k 1} \sigma_{k 2} & \sigma_{k 3} & \ldots & \sigma_{k k}
\end{array}\right]
\end{aligned}
$$

Portfolio risk is given by Eq. 6 .

$$
\sigma_{p}=\sqrt{\sum_{i=1}^{n} w_{i}^{2} \cdot \sigma_{i}^{2}+\sum_{i=1}^{n} \sum_{\substack{j=1 \\ j \neq i}}^{n} w_{i} \cdot w_{j} \cdot \sigma_{i j}}
$$

Where:

$\mathrm{w}_{\mathrm{i}}$ - an individual weight of $\mathrm{i}$-farm (farm`s equity) in a portfolio (total equity of all farms);

$\mathrm{n}$ - total number of farms.

The expected return on equity of portfolio is estimated by the multiplication of individual weights of portfolio $(w)$ and corresponding individual expected returns on equity (the sum of multiplication of each farm's expected ROE and its share in the market portfolio).

$E R O E_{p}=\sum_{i=1}^{n} E R O E_{i} \cdot w_{i}$

Where:

$E R O E_{p}$ - expected portfolio return on equity, $E R O E_{i}$ - the average return on equity of individual farm. 


\section{RESULTS AND DISCUSSION}

The average acreage of cooperatives in the sample was 1429 hectares of the utilised agricultural area (UAA), while the average UAA of agricultural companies was 1102 hectares (Table 1). The equity per hectare of both, agricultural cooperatives and companies displayed high variance, over $130 \%$ and $981 \%$ correspondingly. An explanation of this considerable difference could follow from prevailing specialisation of commercial companies on capital intensive production.

While the median equity of cooperatives was almost twice the median equity of agricultural companies, the average equity of companies exceeded those of cooperatives by twice. It was easier to achieve positive return on equity (ROE) rates for agricultural companies (Table 1).

Out of 535 agricultural farms in the sample, the majority of them (393) made profit and their return on equity was positive over 2009-2012. Only $26.5 \%$ of them (142) generated loss. The cooperatives on average generated losses every year, except for 2011. Only 38\% of cooperatives (175) were profitable during 2009-2012. The average ROE of agricultural companies was positive and significantly higher than was the average ROE of cooperatives over the observed period.

The calculated systematic risk in the Slovak agricultural farms by legal form over the period 2009 2012 was 3\%. The average return (measured as ROE) in the Slovak agriculture over the period 2009 - 2012 was $0.048 \%$, which shows that the profitability of agricultural sector was low. The average risk of the agricultural companies was lower than calculated systematic risk (Table 2). To higher overall average risk contributed particularly cooperatives, with significantly higher risk than those of companies.

The average return on investment to the Slovak agricultural companies would reach $3 \%$ with $2.4 \%$ risk, which means, that return would vary from $0.6 \%$ to $5.4 \%$ and would be positive. Cooperatives would generate loss of $1.9 \%$ of equity, with higher risk (3.5\%) than those of agricultural companies. The return on investment to the cooperatives would vary from $-5.4 \%$ to $1.6 \%$. Agricultural companies are considered to be more efficient, they display higher profitability compared to cooperatives. It can be partially explained by high number of co-owners of the cooperatives, reaching approx. 9 per 100 ha of agricultural land in 2012, compare to 1.2 per 100 ha in agricultural companies.

In addition, there were significant differences in diversifiable farm risk values (Table 2). The diversifiable farm risk reached $11.3 \%$ (difference between the average total risk of a farm and the systematic risk), but the overall farm risk, including the impact of correlation, decreased to $3 \%$.

The average cooperative risk was lower than the average farm risk. Agricultural company risk variability was higher than variability of the cooperative risk, although the cooperative portfolio risk was higher. This can be explained by higher variability of the agricultural company average equity per hectare (Table 1 ).
Table 1 Selected Indicators of the Slovak agricultural farms (2009-2012)

\begin{tabular}{|c|c|c|c|c|c|c|}
\hline Legal Form & Statistics & 2009 & 2010 & 2011 & 2012 & Average \\
\hline \multicolumn{7}{|c|}{ Acreage in hectares } \\
\hline \multirow[t]{4}{*}{ cooperatives } & Mean & 1439 & 1434 & 1427 & 1415 & 1429 \\
\hline & Median & 1175 & 1178 & 1170 & 1174 & 1174 \\
\hline & St. Dev. & 997 & 1001 & 1000 & 983 & 995 \\
\hline & $\mathrm{CV}$ & 0.69 & 0.70 & 0.70 & 0.69 & 0.70 \\
\hline \multirow[t]{4}{*}{ companies } & Mean & 1104 & 1104 & 1102 & 1097 & 1102 \\
\hline & Median & 744 & 728 & 755 & 763 & 747 \\
\hline & St. Dev. & 1129 & 1127 & 1108 & 1100 & 1116 \\
\hline & $\mathrm{CV}$ & 1.02 & 1.02 & 1.01 & 1.00 & 1.01 \\
\hline \multicolumn{7}{|c|}{ Equity per hectare in EUR } \\
\hline \multirow[t]{4}{*}{ cooperatives } & Mean & 1495 & 1479 & 1490 & 1478 & 1486 \\
\hline & Median & 1195 & 1177 & 1226 & 1196 & 1198 \\
\hline & St. Dev. & 1967 & 1974 & 1874 & 1885 & 1925 \\
\hline & $\mathrm{CV}$ & 1.32 & 1.33 & 1.26 & 1.27 & 1.30 \\
\hline \multirow[t]{4}{*}{ companies } & Mean & 3080 & 3071 & 2929 & 3159 & 3060 \\
\hline & Median & 466 & 483 & 521 & 550 & 505 \\
\hline & St. Dev. & 29958 & 30524 & 27790 & 31840 & 30028 \\
\hline & $\mathrm{CV}$ & 9.73 & 9.94 & 9.49 & 10.08 & 9.81 \\
\hline \multicolumn{7}{|l|}{ ROE } \\
\hline \multirow[t]{3}{*}{ cooperatives } & Mean & -0.12 & -0.03 & 0.02 & -0.02 & -0.04 \\
\hline & Median & -0.04 & 0.00 & 0.02 & 0.01 & 0.00 \\
\hline & St. Dev. & 0.27 & 0.24 & 0.21 & 0.29 & 0.25 \\
\hline \multirow[t]{3}{*}{ companies } & Mean & 0.01 & 0.05 & 0.11 & 0.08 & 0.06 \\
\hline & Median & 0.03 & 0.04 & 0.05 & 0.05 & 0.04 \\
\hline & St. Dev. & 0.40 & 0.37 & 0.24 & 0.33 & 0.34 \\
\hline
\end{tabular}

Source: own calculation based on data from the Information Letters of the MoARD SR (2013).

Table 2 The Slovak agricultural farms' systematic risk (2009-2012)

\begin{tabular}{|c|c|c|c|c|}
\hline $\begin{array}{l}\text { Number } \\
\text { of farms }\end{array}$ & $\begin{array}{l}\text { Average } \\
\text { ROE } \\
\text { (aver. } \\
\text { EROE }_{\mathrm{i}} \text { ) }\end{array}$ & $\begin{array}{l}\text { Systematic } \\
\text { (Portfolio) } \\
\text { risk }\left(o_{p}^{\prime}\right)\end{array}$ & $\begin{array}{l}\text { Average } \\
\text { total risk } \\
\text { of a farm } \\
\text { (aver. } o_{\mathrm{i}} \text { ) }\end{array}$ & $\begin{array}{r}\text { Average } \\
\text { equity } \\
\text { per farm } \\
\text { (mil. EUR) }\end{array}$ \\
\hline \multicolumn{5}{|c|}{ Ag. Farms } \\
\hline 996 & $0.048 \%$ & $3.0 \%$ & $14.3 \%$ & 1.52 \\
\hline \multicolumn{5}{|c|}{ Ag. Companies } \\
\hline 535 & $3.0 \%$ & $2.4 \%$ & $16.2 \%$ & 1.13 \\
\hline \multicolumn{5}{|c|}{ Ag. Cooperatives } \\
\hline 461 & $-1.9 \%$ & $3.5 \%$ & $12.1 \%$ & 1.97 \\
\hline
\end{tabular}

Source: own calculation based on data from the Information Letters of the MoARD SR (2013).

\section{CONCLUSION}

Systematic risk is a quantitative measure of a market risk. The higher the systematic risk is in a market, the higher the required return should be. The risk level in agriculture has been partially mitigated by agricultural policy measures. The majority of agricultural farms are unquoted and the assessment of the market value of their 
return and risk calculations can be only based on financial statements.

The Slovak agricultural farms in our sample displayed low profitability over observed period. Significant differences in the levels of return on equity and systematic risk were observed in between of agricultural cooperatives and companies, both prevailing legal forms of agricultural farms in Slovakia. Since the average ROE was higher and the portfolio risk indicator was lower for companies, these could be more attractive for investors. The average risk of individual company however, exceeded the average risk of individual cooperative. Due to higher systematic risk of the agricultural cooperatives, we can expect further decline of their number and their share on the UAA in favour of agricultural companies.

There are several limitations of this study approach, e.g. regional farm distribution was not taken into consideration, questionable reliability of the financial statements used for tax purposes, data sample restricted to two legal forms, even they cultivate the highest share of the UAA. A longer period of observations will enable in the future to verify the conclusions on lower risk level of agricultural companies compare to agricultural production cooperatives.

\section{REFERENCES}

BAGINSKI, S. P. - WAHLEN, J. M. (2003). Residual Income Risk, Intrinsic Values, and Share Prices. The Accounting Review. 78, (1) 327-351. http://dx.doi.org/10.2308/accr.2003.78.1.327

BARKLEY, A. P. - PETERSON, H. - SHROYER, J. (2010). Wheat Variety Selection to Maximize Returns and Minimize Risk: An Application of Portfolio Theory. Journal of Agricultural and Applied Economics. 42, (1) 39-55.

BARRY, P. J. (1980). Capital Asset Pricing and Farm Real Estate. American Journal of Agricultural Economics. 62, (3) 549-553. doi:10.2307/1240213

BREALEY, R. A. - MYERS, S. C. (2008). Principles of Corporate Finance. 9th. edition. International Edition. McGraw-Hill.

CAMPBELL J. - POLK, C. - VUOLTEENAHO, T. (2008). Growth or glamour? Fundamentals and systematic risk in stock returns. Review of Financial Studies, Society for Financial Studies. 23, (1) 305-344. ISSN 0893-9454. doi:10.1093/rfs/hhp029

COHEN, R. B. - POLK, C. - VUOLTEENAHO, T. (2009). The price is (almost) right. Journal of Finance. 64, 2739-2782. doi:10.1111/j.1540-6261.2009.01516.x

DA, Z. 2009. Cash flow, consumption risk, and crosssection of stock returns. Journal of Finance, 64, 923956. doi:10.1111/j.1540-6261.2009.01453.x

FAMA, E. F. - FRENCH, K .F. (1995). Size and bookto-market factors in earnings and returns. Journal of Finance, 50, 131 - $155 . \quad$ doi:10.1111/j.15406261.1995.tb05169.x
GEMPESAW, C. M. - TAMBE, A. M. - NAYGA, R. M. - TOENSMEYER U. C. (1988). The Single Index Market Model in Agriculture. Northeast Journal of Agricultural and Resource Economics. 17, (2) 147-155.

HUBBS, T. - KUETHE, H. BAKER, T. G. (2009). Evaluating the Dynamic Nature of Market Risk. [online]. In Conference on Applied Commodity Price Analysis, Forecasting, and Market Risk Management in its series 2009. St. Louis. Missouri. Discussion Paper No. 53037. Available at: http://ageconsearch.umn.edu/ bitstream/53037/2/confp03-09.pdf

Information Letters of the Ministry of Agriculture and Rural Development SR, 2013.

LEE, J. - JANG, S. (2006). The systematic-risk determinants of the US airline industry. Tourism Management. 28, (2) 434-442. http://dx.doi.org/10.1016/j.tourman.2006.03.012

LIBBIN, J. D. - KOHLER, J. D. - HAWKES J. M. (2004). Does Modern Portfolio Theory Apply to Agricultural Land Ownership? Concepts for Farmers and Farm Managers. Journal of the American Society of Farm managers and Rural Appraisers. 85-96.

LINTNER, J. (1965).The Valuation of Risk Assets and the Selection of Risky Investments in Stock Portfolios and Capital Budgets. Review of Economics and Statistics. 47, (1) 13-37. doi:10.2307/1924119

MARKOWITZ, H. M. (1952). Portfolio Selection. Journal of Finance. 7, (1) 77-91. doi:10.1111/j.15406261.1952.tb01525.x

MUMEY, G. - BURDEN, B. - BOYDA, A. (1992). Measurement of Farm Risk: Alberta Crop Production. Canadian Journal of Agricultural Economics. 40, (1) 7191. doi:10.1111/j.1744-7976.1992.tb03678.x

PETERSON, P. E. - LUETHOLD, R. M. (1987). A portfolio approach to optimal hedging for a commercial cattle feedlot. Journal of Futures Markets. 7, (4) 443457. doi:10.1002/fut.3990070407

PRATTLEY, D. J. - MORRIS, R. S. - STEVENSON, M. A. THORNTON, R. (2007). Application of portfolio theory to risk-based allocation of surveillance resources in animal populations. Preventive Veterinary Medicine. 81 (1-3), 56-69. doi:10.1016/j.prevetmed.2007.04.009

SHARPE, W. F. (1963). A Simplified Model for Portfolio Analysis. Management Science. 9, (2) 77-93. doi:10.1287/mnsc.9.2.277

SHARPE, W. F. 1964. Capital Asset Prices: A Theory of Market Equilibrium under Conditions of Risk. Journal of Finance. 19, (3) 425-442. doi:10.1111/j.15406261.1964.tb02865.x

TURVEY, C. G. - DRIVER, H. C. (1987). Systematic and Non-systematic Risks in Agriculture. Canadian Journal of Agricultural Economics. 35, (2) 387-401. doi:10.1111/j.1744-7976.1987.tb02236.x 